\title{
FOREWORD
}

It was a great pleasure and honor to welcome Professor Neil J. Smelser and his wife, Sharin, to Humboldt University in Berlin. We were glad to have him with us for a month as the second Georg Simmel Guest Professor. This professorship, in the name of one of the founding fathers of sociology in Germany, was established by the newly founded Department of Social Sciences at a reconstructed Humboldt University in 1993. In this year we celebrated the centenary of the first course taught in sociology at the Friedrich Wilhclms University, "Ubungen auf dem Gebiete der Sociologie," without a fee, by someone named "Dr. Simmel," as the course calendar informs us."

Georg Simmel, one of sociology's major historical figures, studied and taught at Berlin University thirty-eight years without ever attaining a full professorship. There were a number of reasons for this: his professional success, his promotion of female students, his "modernity," his casual style, and anti-Semitism (Simmel was an assimilated Jew who converted to Protestantism). Somewhat belatedly, yet in his

*For full documentation, see the special issue of the Berliner Journal für Soziologie 3, no. 2 (1993), on Georg Simmel, editcd by the Department of Social Sciences at Humboldt University. 
spirit, we inaugurated a Georg Simmel guest professorship with a colloquium entitled "Berlin and Its Intellectual Culture" at which Lewis A. Coser, who has done so much for the reception of Simmel in the United States, received an honorary degree from Humboldt University on the occasion of his eightieth birthday and the sixtieth "anniversary" of his expulsion from Germany in 1933.

Actually, Neil Smelser needs no introduction. He is well known in Germany and famous in the Anglo-American world. Let me illustrate that by way of an anecdote. When I told a colleague in Berlin that Smelser was going to serve as the 1995 Georg Simmel Guest Professor, he replied, "Jesus, is he still alive? He surely must be in his late eighties!" Now, I can convince him that Neil Smelser is not that old in age and that he is still young in his thinking. But my colleague was not entirely misled; to the contrary, he gave ample evidence of how long Smelser has remained vividly alive in the collective memory of his German fellow sociologists. He referred to the famous book, Economy and Society (1956), which Smelser coauthored with Talcott Parsons. By that time, he had earned his B.A. in Social Relations at Harvard College, had studied philosophy, politics, and economics at Magdalen College at Oxford University, and was working on his Ph.D. (granted in 1958). So, before he finished his doctoral dissertation he was coauthor with Parsons of a prominent book that was translated into Italian and Japanese, but unfortunately never into German. In short: Neil Smelser was famous before he had a doctorate-unthinkable in German academic life.

Economy and Society and his doctoral dissertation, published as Social Change in the Industrial Revolution (1959), give us a hint as to the characteristics of his thought: first, a strong theoretical bent, whichgiven the impact of Talcott Parsons-does not come as a surprise; but from the beginning he struggled to resolve the problems and weaknesses of structural functionalism: Robert King Merton on the East Coast, Neil Smelser on the West Coast. He started teaching in Berkeley in 1958 , where he remained until he moved to Palo Alto in 1994, to 
serve as the director of the Center for Advanced Study in the Behavioral Sciences at Stanford. Like Bob Merton, Neil Smelser retains the strengths while eliminating the weaknesses of structural functionalism. Instead of theorizing stability and order, he looks at social change and social movements; instead of accounting for order and change by abstract mechanisms like social control and socialization, he analyzes the precise dynamics of change; instead of dealing with individual actors and systems, he investigates collective action and institutional domains like the economy, education, and the family in a historicalempirical, not in an abstract-analytical, vein. The results are classics by now: Social Change in the Industrial Revolution (1959), for differentiation theory; Theory of Collective Behavior (1962), for research on social movements; The Sociology of Economic Life ([1962] 1975), for economic sociology; and quite recently, Social Paralysis and Social Change (1991). Theory is not a value in itself, but has to be taught. Among the numerous attempts to grasp the hard core of this impossible discipline I will mention only two: Sociological Theory, with Stephen Warner (1976), which I still regard as one of the best systematic histories of sociology, and Sociology (1994), which appeared as volume I of the UNESCO/ Blackwell series in the social sciences.

A second trait of his work concerns the methodological side of the social sciences. In postmodern times favoring intuition, difference, and pluralism, this seems particularly outdated. Yet serious sociological analysis may very well profit from his reflections on historicalcomparative methods. In this respect, I may only mention Comparative Methods in the Social Sciences (1976), which I consider still one of the most valuable sources for historical-comparative reasoning. At least this was a revelation for us as students in a remarkable seminar in Heidelberg with Reinhard Bendix, M. Reiner Lepsius, and Wolfgang Schluchter, when we studied Bendix, Barrington Moore, Victoria Bonnell, Theda Skocpol-and Neil Smelser.

Still another line of thinking emerges when we turn to the fields Neil Smelser investigated. First, economy and its hegemonic meaning 


\section{xii / Foreword}

in modern industrial society led him to plead for a true economic sociology, as The Sociology of Economic Life and The Handbook of Economic Sociology (1994), edited with Richard Swedberg, attest. Second, higher education and the role of the university in Western societies has repeatedly attracted his sociological attention. Let me mention the epilogue in Parsons's and Platt's The American University (1973) and the reflections in The Changing Academic Market ( 1980 ). Third, he has contributed to our understanding of the family. For a trained psychoanalyst who took psychoanalysis seriously while teaching sociology at Berkeley, this may not come as a surprise. This interface of sociological and psychoanalytical reasoning becomes visible in the book Themes of Work and Love in Adulthood (1980), coedited with Erik Erikson, in his portrait "The Victorian Family" (1982), and in the essay "The Historical Triangulation of Family, Economy, and Education" (1978) with Sydney Halpern.

But there is not only Neil Smelser the scholar, there is Neil Smelser the manager. It seems to be a trademark of this generation of institution builders like M. R. Lepsius and N. J. Smelser that they do not work entirely for their own fame but invest a great deal of energy in sustaining the discipline. Do not worry, I will not count the numerous committees and councils on which he has served. He played and still plays a crucial role in the social science establishment; he helped rebuild sociology at Harvard University, he was vice president of the International Sociological Association after our colleague Artur Meier, and is serving as president of the American Sociological Association in 1996-1997. He initiated the famous American-German Theory conferences in the eighties. One of the topics of these conferences was The Micro-Macro Link (1981). And it is the generic problematics of sociology-micro, meso, macro, and global sociology-to which the Georg Simmel Lectures in the summer of 1995 were devoted.

Hans-Peter Müller

Professor of Sociology,

Humboldt University 